Mongolian Academy of Sciences
Mongolian Journal of Chemistry
Institute of Chemistry \& Chemical Technology

\title{
Activated carbons from Mongolian coals by thermal treatment
}

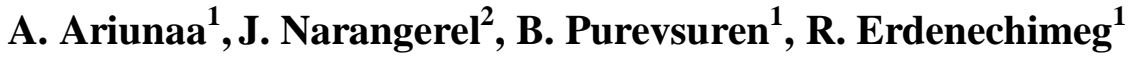 \\ ${ }^{1}$ Institute of Chemistry and Chemical Technology, MAS, Ulaanbaatar 51, Mongolia \\ ${ }^{2}$ Central Laboratory for Coal Research, Mineral Resources Authority of Mongolia, \\ POB297, Ulaanbaatar 210628, Mongolia.
}

\begin{abstract}
Mongolian different rank coals were used as raw material to prepare activated carbons by physical activation method. The coal derived carbons were oxidized with nitric acid in order to introduce surface oxygen groups. The ultimate elemental analysis, scanning electron microscopy, surface area, pore size distribution analysis and selective neutralization method were used to characterize the surface properties of activated carbons, oxidized carbons and raw coals. The effect of coal grade on the adsorption properties of the carbons were studied. It was concluded that Naryn sukhait bituminous coal could be serve as suitable raw material for production of activated carbons for removal of heavy metal ions from solution.
\end{abstract}

Keywords: lignite, subbituminous and bituminous coals, activated carbon, oxidized carbon

Introduction

$\mathrm{M}$ ongolia is a country with rich coal resources. Coal has been believed to be the major energy source among fossil fuels in the coming century because of its easy availability. Total geological resources of coal are 163 billion tones and a proven coal reserve is 9.3 billion tones [1]. In 2010 Mongolian coal production has been increased to 23 million tones, from which 17 million tones were exported to China. Coal is composed mostly of lignite, subbituminous and bituminous coals.

The presence of contaminant heavy metal ions like cadmium, mercury and lead in the industrial area of Ulaanbaatar city is a growing problem due to their high toxicities. Direct use of activated carbon [2] or some of their modified forms such as oxidized carbons [3] for the removal of the toxic metal ionic pollutants present in waste water is of considerable importance.
To resolve the problems of environmental pollutions we need to investigate the possibility of obtaining activated carbons with certain adsorbing and filtering ability from different kind of coals, which are the cheapest raw materials in Mongolia. In principle, the processes for the preparation of active carbons can be divided into two categories - physical and chemical methods. The physical method consists of carbonization of the precursor followed by gasification of the resulting char by steam or by using of carbon dioxide [4].

The objective of the present work was to study the features on thermal decomposition of Mongolian Shivee-Ovoo lignite, Sharyn gol, Alagtogoo subbituminous coals, and Naryn sukhait bituminous coal, to establish the possibility to obtain adsorbent materials physical methods from these coals. 


\section{Experimental}

Bituminous and low rank coals from some main deposits of Mongolia were used as a precursor in this study. The proximate and elemental analysis of the coals are summarized in Table 1 . The coals were selected samples with low to medium ash content from their respective deposits.

table 1. proximate and elemental analysis of coals

\begin{tabular}{|c|c|c|c|c|c|c|c|c|c|}
\hline \multirow[t]{2}{*}{ Code } & \multirow[t]{2}{*}{ Samples } & \multicolumn{3}{|c|}{$\begin{array}{c}\text { Proximate analysis } \\
\%\end{array}$} & \multicolumn{4}{|c|}{$\begin{array}{c}\text { Elemental analysis data } \\
\%\end{array}$} & \multirow{2}{*}{$\begin{array}{l}\mathrm{H} / \mathrm{C} \\
\text { atomic } \\
\text { ratio }\end{array}$} \\
\hline & & $\mathrm{W}^{\mathrm{a}}$ & $\mathrm{A}^{\mathrm{d}}$ & $\mathrm{V}^{\mathrm{daf}}$ & $\mathrm{C}$ & $\mathrm{H}$ & $\mathrm{N}$ & $\mathrm{O}^{\mathrm{a}}$ & \\
\hline So & $\begin{array}{c}\text { Shivee- } \\
\text { Ovoo } \\
\text { (lignite) }\end{array}$ & 10.9 & 18.1 & 46.8 & 64.7 & 5.1 & 0.3 & 29.9 & 0.94 \\
\hline $\mathrm{AT}$ & $\begin{array}{c}\text { Alagtogoo } \\
\text { (subb) }\end{array}$ & 5.4 & 8.1 & 47.0 & 75.9 & 5.2 & 1.2 & 17.7 & 0.83 \\
\hline SG & $\begin{array}{c}\text { Sharyn gol } \\
(\text { subb) }\end{array}$ & 6.9 & 7.7 & 36.8 & 79.0 & 5.8 & 1.2 & 14.0 & 0.89 \\
\hline NS & $\begin{array}{l}\text { Naryn } \\
\text { sukhait } \\
(\text { hvb) }\end{array}$ & 1.65 & 3.7 & 32.9 & 84.9 & 4.4 & 0.5 & 10.2 & 0.67 \\
\hline
\end{tabular}

Carbonized chars named SOC, ATC, SGC and NSC (Shivee-Ovoo, Alagtogoo, Sharyn gol and Naryn sukhait coalscarbonized) were prepared from ShiveeOvoo lignite, Alagtogoo, Sharyn gol subbituminous and Naryn sukhait bituminous coals. The coals having particle size from 3.0 to $1.5 \mathrm{~mm}$, were carbonized in a retort at temperature $800^{\circ} \mathrm{C}$, with heating rate of $20^{\circ} \mathrm{C} \mathrm{min}^{-1}$, for $270 \mathrm{~min}$.

Activated carbon named SOAC, ATAC, SGAC and NSAC (Shivee-Ovoo, Alagtogoo, Sharyn gol and Naryn sukhait coals-carbonized chars-activated) were prepared from Shivee-Ovoo lignite, Alagtogoo, Sharyn gol subbituminous and Naryn sukhait bituminous coals. The carbonized chars were activated in a vertical quartz reactor at $800^{\circ} \mathrm{C}$, with heating rate of $5^{\circ} \mathrm{C} \mathrm{min}^{-1}$, in a steam flow (rate $160 \mathrm{~cm}^{3} / \mathrm{min}$ ), between from 60 to $220 \mathrm{~min}$.

Oxidized carbon named ATACO, NSACO (Alagtogoo, Naryn sukhait coalsactivated carbons-oxidized) were prepared from Alagtogoo subbituminous, Naryn sukhait bituminous coals. The activated carbons were oxidized with boiling $7.5 \mathrm{~N}$ $\mathrm{HNO}_{3}$ (solid:liquid-1:10) between from 6 to $12 \mathrm{~h}$. After oxidation, the samples was recovered and washed thoroughly with hot distilled water until they are free of nitrate ions.

Adsorption of metal ions from solution. About $0.1 \mathrm{~g}$ of carbon was doped into $50 \mathrm{ml}$ of solution having the known initial concentration (0-1.6 $\mathrm{mM})$ containing metal ions $\mathrm{Pb}$. Adsorption experiments were conducted at $25^{\circ} \mathrm{C}$ for 48 hours. Atomic adsorption spectrometer (AAS) was employed to determine the concentration of stock solution and the equilibrium concentration of metal ions in solutions after adsorption. The metal ions adsorbed on active carbon were calculated as following;

\section{$\mathrm{Ma}=(\mathrm{Co}-\mathrm{Ce}) * \mathrm{~V} / 1000 * \mathrm{Wc}$}

where $\mathrm{Co}$ and $\mathrm{Ce}$ refer to initial and equilibrium concentration of metal ion in solution individually, $\mathrm{mM}$; $\mathrm{V}$ is the volume of solution. For all experiments, the volume $\mathrm{V}$ is equal to $50 \mathrm{ml}$; $\mathrm{Wc}$, the weight of carbon sample, $\mathrm{g}$; $\mathrm{Ma}$, the amount of metal ions adsorbed by carbons, $\mathrm{mmol} / \mathrm{g}$ [5].

\section{Results and Discussion}

Carbonization. Table 2 shows the results of the carbonization experiments. Compared with Shivee-Ovoo lignite, Alagtogoo, Sharyn gol subbituminous coals, carbon content is higher for Naryn sukhait bituminous coal, which caused by its higher rank of coalification. That is why; the yield of char from Naryn sukhait coal was higher than that of other coals. The coalification was also the reason for the marked difference in carbonization product yield obtained from Alagtogoo and Sharyn gol subbituminous coal. Table 1 indicates that the atomic ratio of $\mathrm{H} / \mathrm{C}$ in Shivee-Ovoo lignite reaches 0.94 , while Naryn sukhait bituminous coal has the ratio only 0.67 , showing that lignite mainly contains aliphatic structure, which can be easily decomposed during carbonization. 
Table 2. Yield of the carbonization products

\begin{tabular}{|c|c|c|c|c|}
\hline \multirow{2}{*}{ № } & Sample & \multicolumn{3}{|c|}{ Product yield, (\%) } \\
\cline { 3 - 5 } & Char & $\begin{array}{c}\text { Tar and } \\
\text { water }\end{array}$ & $\begin{array}{c}\text { Gas+ } \\
\text { loss }\end{array}$ \\
\hline 1 & Shivee-Ovoo & 50.11 & 26.29 & 23.6 \\
\hline 2 & Alagtogoo & 58.85 & 19.82 & 21.33 \\
\hline 3 & Sharyn gol & 64.04 & 16.46 & 19.5 \\
\hline 4 & $\begin{array}{c}\text { Naryn } \\
\text { sukhait }\end{array}$ & 70.10 & 13.57 & 16.33 \\
\hline
\end{tabular}

Physical activation. To obtain an adsorbent material from these chars after carbonization, it is necessary to activate chars with heated steam to increase their pore structure. The chars of Shivee-Ovoo, Alagtogoo, Sharyn gol and Naryn sukhait coals were activated in a vertical quartz reactor at temperature $800^{\circ} \mathrm{C}$, with heating rate of $5^{\circ} \mathrm{C} \mathrm{min}^{-1}$, under steam, between from 60 to $220 \mathrm{~min}$. Char fractions with a particle size range between 1.5-0.63 mm were selected for the study. Table 3 shows some properties of the active carbon. Active carbons had higher contents of ash and volatile matter compared with raw chars. With increasing activation time, the contents of the mineral matter in carbons were increased due to their partial oxidation and decomposition of organic matter. The datas also showed that the yield of active carbons were decreased with increasing time of activation, indicating the oxidation and decomposition degrees of organic matter are different for the different types of chars.

Table 3. Properties of the active carbons obtained at temperature $800^{\circ} \mathrm{C}$

\begin{tabular}{|c|c|c|c|c|c|c|c|c|c|c|c|c|c|c|c|c|}
\hline & & 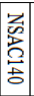 & 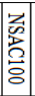 & & s. & 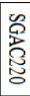 & ถి & 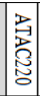 & $\begin{array}{l}\text { 党 } \\
\text { 总 } \\
\text { 号 }\end{array}$ & $\begin{array}{l}\text { 龺 } \\
\text { 总 } \\
\text { 吉 }\end{array}$ & 常 & 常 & & & $\check{8}$ & ᄋి \\
\hline 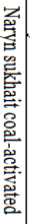 & 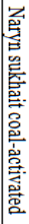 & 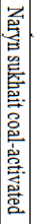 & 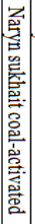 & 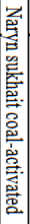 & 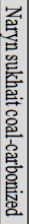 & 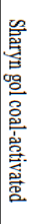 & 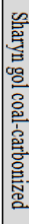 & 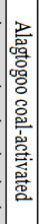 & 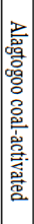 & 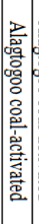 & 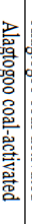 & 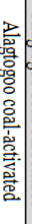 & 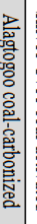 & 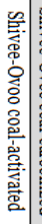 & 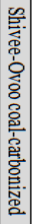 & 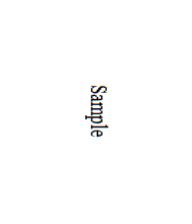 \\
\hline$\tilde{\Xi}$ & $\ddot{\circ}$ & 客 & $\overrightarrow{8}$ & 8 & ' & $\mathbb{O}$ & . & N్ర & : & 客 & $\overrightarrow{8}$ & 8 & ' & N্ & . & Time, min \\
\hline a & & $\begin{array}{l}\infty \\
ٌ \\
\sim\end{array}$ & 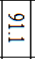 & \begin{tabular}{|l|l}
$\infty$ \\
$\infty$ \\
$\infty$
\end{tabular} & & $\stackrel{+}{\sharp}$ & . & 㕝 & $\stackrel{9}{\mathrm{i}}$ & \begin{tabular}{|l|}
$\infty$ \\
$\infty$ \\
$\infty$
\end{tabular} & $\begin{array}{c}\infty \\
\infty \\
\infty \\
\end{array}$ & 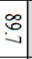 & & \begin{tabular}{|c|}
\multirow{2}{*}{} \\
\end{tabular} & & Yield, \% \\
\hline & & 2 & $\omega$ & $\backsim$ & $\rightarrow$ & $\Xi$ & 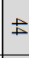 & ్ㅀ & ㄴ.̆ & $\vec{G}$ & $\infty$ & 밍 & $\rightarrow$ & $\alpha$ & 9 & $\begin{array}{c}\text { Iodine adsorption, } \\
\mathrm{mg} / \mathrm{g}\end{array}$ \\
\hline & 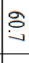 & $\underset{N}{N}$ & $\because$ & $\vec{a}$ & $\omega^{\prime}$ & 幽 & $\begin{array}{l}\omega \\
\omega\end{array}$ & 岕 & 岕 & $\underset{\sim}{\sim}$ & $\vec{\square}$ & is & $\doteqdot$ & $\tilde{\ddagger}$ & 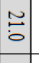 & Iodine number, $\%$ \\
\hline$\stackrel{t}{*}$ & 은 & $\underset{\sim}{\breve{N}}$ & ๑ & $\overrightarrow{0}$ & & 岕 & . & 㭊 & 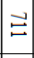 & . & |' & ' & . & \&े & & $\begin{array}{c}\text { Surface area, } \\
\left(\mathrm{N}_{2}, 77 \mathrm{~K}\right),\left(\mathrm{m}^{2} / \mathrm{g}\right)\end{array}$ \\
\hline$\ddagger$ & & $\vdots$ & $\approx$ & 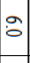 & $\vec{a}$ & $\overrightarrow{0}$ & $\stackrel{\Xi}{\sim}$ & $\begin{array}{l}\vec{\infty} \\
\dot{\infty} \\
\dot{\infty}\end{array}$ & 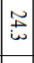 & i & $\underset{\infty}{:}$ & $\stackrel{\vec{N}}{i}$ & $\vec{N}$ & $\approx$ & $\stackrel{\sim}{\circ}$ & Ash, $A^{d}, \%$ \\
\hline & & 5 & io & & $1-$ & $-i$ & $\dddot{\sim}$ & 岕 & $\rightarrow$ & $\omega$ & $\tilde{0}$ & $\vec{a}$ & $\because$ & $\omega$ & $\ddot{\mid}$ & $\begin{array}{c}\text { Volatile matter, } \\
V^{\text {daf }} \%\end{array}$ \\
\hline
\end{tabular}

The adsorption ability of obtained adsorbent materials has been determined by iodine adsorption and the results of analysis are given in Figure 1. The iodine adsorption capacity of active carbon was increased with increasing activation time from 60 to $180 \mathrm{~min}$. Sharp reduction (almost 2 times) in the iodine adsorption capacity was observed in case of Naryn sukhait char, during its activation from 180 to $220 \mathrm{~min}$. The results may indicate that with increasing activation time more than 180 min, intensive destruction of the carbon internal structure takes place and causes reduction in the porosity and micropore volume.

Active carbon obtained from Naryn sukhait coal by physical activation had highest iodine adsorption capacity $(60.7 \%)$ and lowest ash content (7.1\%) compared with the carbons obtained from other coals. These values were also comparable with commercial carbon obtained from wood (BAU-A carbon data from Alcoholic and Wine Industries according to Russian standard GOST 6217-74; iodine adsorption capacity (60\%) and ash content (6\%)) [6]. Most suitable condition for the physical activation was; temperature $800^{\circ} \mathrm{C}$, time 180 minutes.

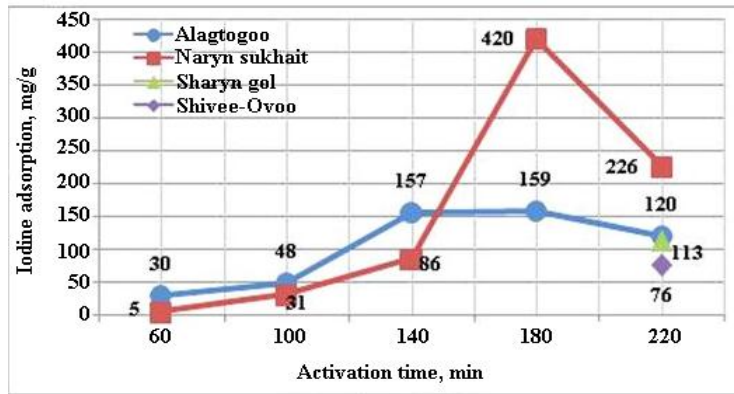

Figure 1. Comparison of iodine adsorption of active carbons

The surface area measurement of obtained adsorbent materials from investigated samples have been determined by reference comparison method and the results of analysis are given in Figure 2. The dates show that surface area of active carbon obtained from Shivee-Ovoo coal has higher than other coals. Shivee-Ovoo active carbon has high adsorption capacity, but low hardness and yield of this active 
carbon could present some disadvantages compared to other active carbons.

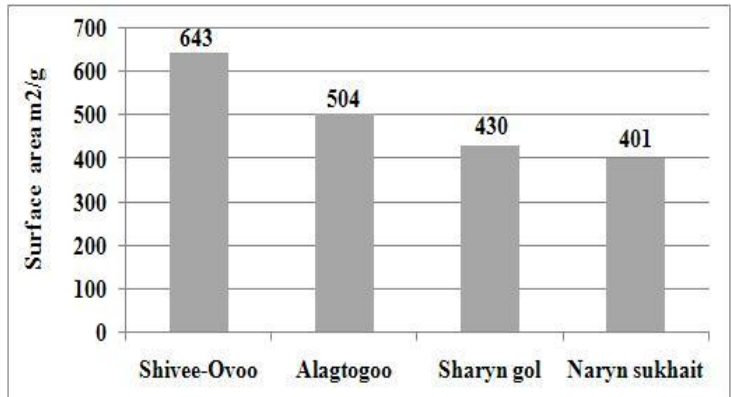

Figure 2. The surface area of Shivee-Ovoo, Alagtogoo, Sharyn gol and Naryn sukhait active carbons. (activation time $220 \mathrm{~min}$ )

Measurements of total pore volume of the active carbons have been determined by multi point BET method [7] and the results of analysis are given in Figure 3. Mesoand macropores were dominant in the pore size distribution of the coal derived active carbons and total pore volumes range from $0.43-0.64 \mathrm{ml} / \mathrm{g}$.

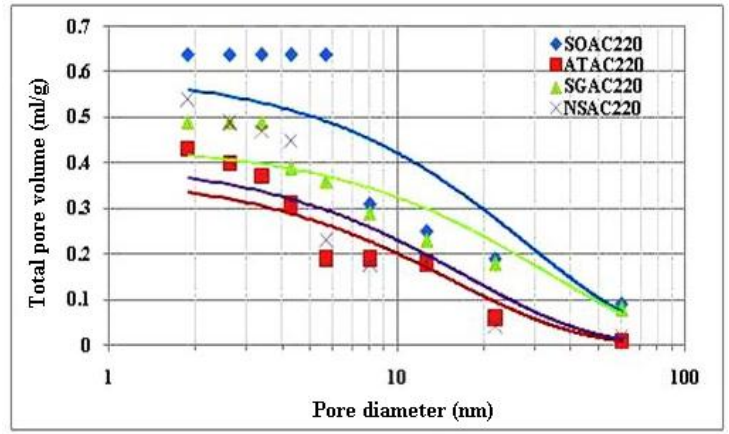

Figure 3. The total pore volume curve of Shivee Ovoo, Alagtogoo, Sharyn gol and Naryn sukhait active carbons. (activation time $220 \mathrm{~min}$ )

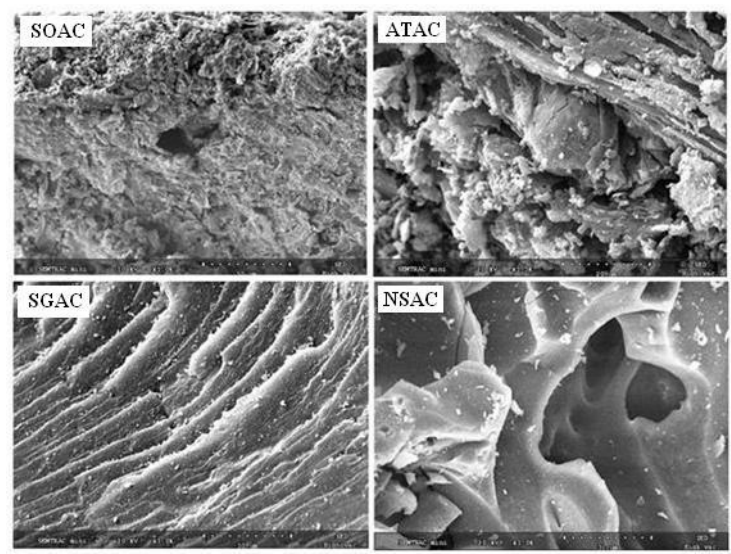

Figure 4. SEM microphotographs of activated carbons

Scanning electron microscopic (SEM) analysis has been used to estimate the porosity of active carbon particles. The images in Figure 4 show that the active carbon obtained from Naryn sukhait coal by physical activation has very well developed porosity compared with the carbons obtained from other coals. Active carbon obtained from Naryn sukhait coal had following properties; yield $65.7 \%$, ash content $6.5 \%$, iodine adsorption $226 \mathrm{mg} / \mathrm{g}$, average diameter of pore $8.62 \mathrm{~nm}$. SEM microphotographs showed that this carbon was well fused and swelled during activation.

Oxidation of the active carbons by nitric acid has increased the yield of volatile compounds and decreased the ash content. Oxidized carbons had relative higher content of carboxylic and lactone-lactole functional groups, lower content of phenolic group compared with parent chars [8]. Maximum adsorption capacities of ATCO and NSCO for $\mathrm{Pb}^{2+}$ ion were 0.13 $\mathrm{mmol} / \mathrm{g}$ and $0.14 \mathrm{mmol} / \mathrm{g}$ respectively, when the concentration of the solution were in the range of 0.4-0.6 mmol. As shown in Figure 5, approximately $90 \%$ of $\mathrm{Pb}^{2+}$ ion could be removed from solution at concentration of $0.2 \mathrm{mM}$. At higher concentration the efficiency of the removal gradually decreased.

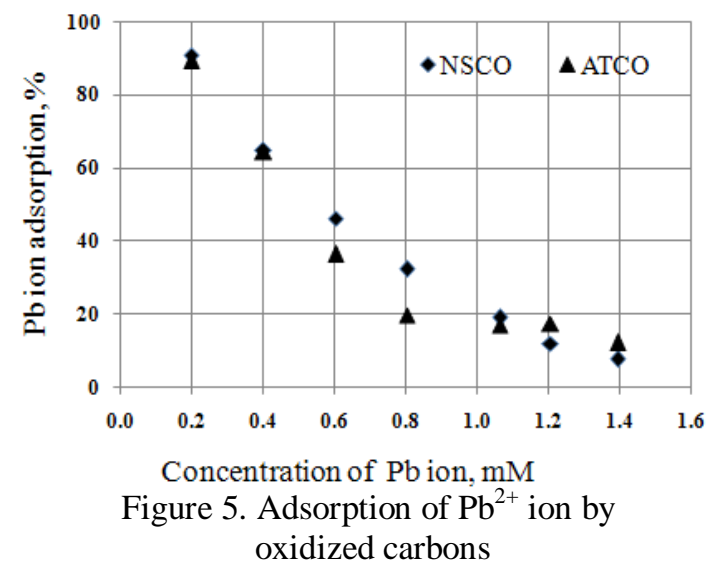

\section{Conclusions}

1. Coalification row of the samples by Russian classification could be ordered as following; Shivee Ovoo (B2)< Sharyn gol (B3-D) $<$ Alagtogoo (D)<Naryn sukhait $(\mathrm{G})$. 
2. Carbon yields are decreasing with activation time while the surface areas of the carbons are increasing. Most suitable condition for the char activation was found to be as - temperature $800^{\circ} \mathrm{C}$ and time $180 \mathrm{~min}$. Active carbon obtained from Naryn sukhait coal had relative higher iodine adsorption capacity showing that this coal is very suitable raw material for production of high surface active carbons.

3. Char yields are increasing with coalification row. Char obtained from Naryn sukhait coal had highest yield (70.1\%) and lowest ash content $(4.6 \%)$ compared with other chars.

4. Pore structure of the active carbons consists of mainly meso- and macropores and have total pore volume from 0.43 to $0.64 \mathrm{ml} / \mathrm{g}$. Total pore volume decreases in following row : SOAC220>NSAC220>SGAC220>AT AC220. Active carbon obtained from Naryn sukhait coal had highest yield (65.7\%), lowest ash content (6.5\%), high iodine adsorption (226 mg/g), relative narrow pore diameter $(8.62 \mathrm{~nm})$ and highest micropore volume $(9.26 \%)$. Also the active carbon has well swelled and fused structure as seen from the SEM analysis. Raw coals have aromatic, aliphatic structures with carbonyl and hydroxyl groups, while the active carbons contain more aromatic structure and hydroxyl groups. Increase of the carbonyl and hydroxyl groups in the oxidized carbons confirms the intensive oxidation of active carbons.
5. Adsorption of $\mathrm{Pb}^{2+}$ cation from solution by oxidized carbons from Naryn sukhait and Alagtogoo coals were highest or $0.13 \mathrm{mmol} / \mathrm{g}, 0.14 \mathrm{mmol} / \mathrm{g}$, when the concentration of the solution were in the range of 0.4-0.6 mmol. Adsorption of $\mathrm{Pb}^{2+}$ cation has been decreased from $90 \%$ to $10 \%$ with increasing concentration of solution.

\section{References}

1. Gombosuren Y. Review of Mongolian mineral research. Ulaanbaatar: 2002.

2. Ahmadpour A, Do DD. The preparation of active carbons from coal by chemical and physical activation. Carbon 1996;34:471-9.

3. Jia YF, Thomas KM. Adsorption of cadmium ions on oxygen surface sites in activated carbon. Langmuir 2000;16:1114-22.

4. Kienle H, Baeder E. Activated carbon can be used at the industrial factory, Chemistry, 1984. p. 215.

5. J.Narangerel, Sh.Monkhjargal, A.Ariunaa, Adsorption of heavy metal ions on oxidized carbon from coal. Proceedings of the Mongolian Academy of Sciences. UB. 2004. №2. p. 16-28.

6. Wood crushed activated carbon. Specifications. GOST 6217-74

7. Beijing JWGB Science and Technology Co., Ltd. Beijing. 2010. p 30.

Y.F.Jia, B.Xiao, K.M.Thomas. Adsorption of Metal Ions on Nitrogen surface Functional Groups in Activated carbons. Langmuir 2002;18:470-478. 